\title{
BASIC RESEARCH OF LUNG CANCER IN-VITRO: MEASUREMENT METHODS, NEW POSSIBILITIES AND PERSPECTIVE
}

\section{Jovana Todosijević', Jovan Luković' , Jasmina Obradović3, Vladimir Jurišićc ${ }^{*}$}

${ }^{1}$ Institute of Biology and Ecology, Faculty of Science, University of Kragujevac, Kragujevac, Serbia

${ }^{2}$ Institute of Chemistry, Faculty of Science, University of Kragujevac, Kragujevac, Serbia

3Institute for Information Technologies Kragujevac, Department of Sciences, University of Kragujevac, Kragujevac, Serbia

4 Faculty of Medical Sciences, University of Kragujevac, Kragujevac, Serbia

\begin{abstract}
Epidemiological data indicate that in the last period there has been an increase in the number of malignancies and among them lung cancer is one of the most common forms. In vitro studies based on the usage of immortalized cell lines are an important source of scientific knowledge for understanding of the mechanism of cell growth, proliferation and cell death. In this paper, the most commonly used methods for in vitro research in NSCLC (non-small cell lung cancer) based on testing the effects of new compounds to determine the degree of apoptosis, necrosis, cell proliferation as well as their significance are discussed. So far, techniques of working with monolayer cultures have been mainly used. In the future, it is recommended to use a $3 D$ system, knockout cell line and to conduct additional studies regarding the use of organoids or spheroids, as well as the application of new techniques to better understand the complex processes of carcinogenesis and the action of biologically active compounds.
\end{abstract}

Keywords: NSCLC, EGFR, cell line, mutation, in vitro method, MTT, Western blot, Flow cytometry, CRISP/cas

\section{INTRODUCTION}

Epidemiological data indicate that recently there has been an increase in the number of malignancies. They are one of the predominant causes of death in our country and in world. The most common lung cancer type is non-small-cell lung carcinoma (NSCLC) (85\%) highly associated with cigarette consumption $[1,2]$.

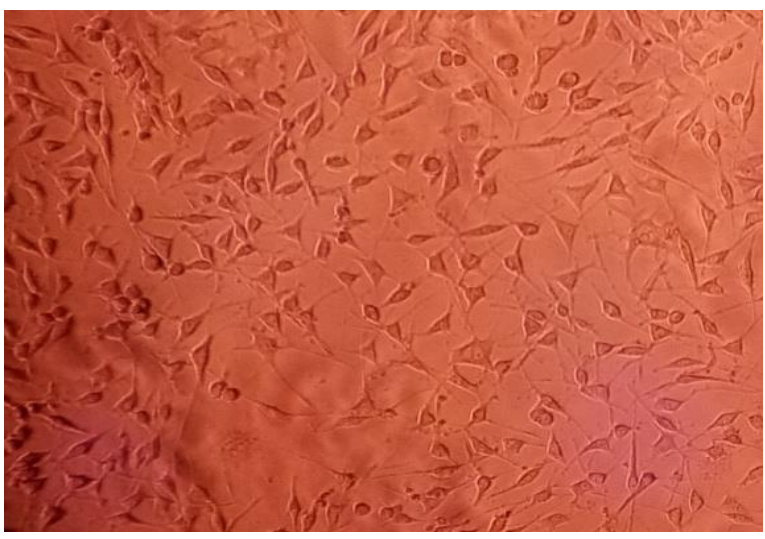

Figure 1. Lung cancer cell culture for in-vitro examination.

In vitro studies based on the use of immortalized cell lines are a valuable source of scientific knowledge for understanding of the mechanism of cell growth, proliferation and cell death. Also, in-vitro research can help us to apply new potential drugs, synthetic compounds, as well as to test their toxicity, which is not possible in humans.

Numerous cell lines isolated from patients with lung tumors used for research, which are described and characterized in great detail, include: H460, H1299, H1975, H23 and H358 (3). Cell lines are useful because they can be used not only to study the signaling processes associated with tumor formation, carcinogenesis, but also with the mechanism of action of newly synthesized drugs $[4,5]$.

\section{INVESTIGATION OF NSCLC}

A review of the literature indicates that the most studied phenomena for NSCLC cell lines include the investigation of cell growth and cell death (apoptosis). Investigation of cell death receptors, cell signaling and mechanism of resistance to the newly synthesized drugs as potential therapeutic medicaments are investigated most often. Genomic and epigenomic phenomena involved in that process indicate the role of $\mathrm{Rb}$ (Retinoblastoma) genes, the Bcl-2 (B-cell lymphoma) family genes, the TNF (Tumour Necrosis Factor Family) genes, and perhaps the most studied EGFR (Epidermal Growth Factor Receptor) gene [6]. According to their function in the cell, they are dividing into pro-apoptotic ones that lead to apoptosis and anti-apoptotic ones that inhibit it. The most well-known mechanism of apoptosis cell regulation is through an increase in pro-apoptotic (Bax) and a decrease of anti-apoptotic proteins (Bcl-2), suppression of matrix metalloproteinases (MMP 2) [7, $8,9]$.

\footnotetext{
*jurisicvladimir@gmail.com
} 
Recently, an enormous number of scientific publications indicate the significant role of epidermal growth factor receptor (EGFR) in NSCLC [10, 11, 12]. This trans-membrane receptor plays a key role in important cellular signaling pathways. EGFR is also a target for treatment, most often with tyrosine kinase inhibitors (TKIs) and monoclonal antibodies. For in vitro research, many potential drugs can be tested, and only those with the best effects can be included in further clinical phases of application. Apart from the best-known EGFR, the key molecules in the NSCLC cell signaling network are STAT3 (Signal transducer and activator of transcription 3), YAP1 (YES-Associated Protein 1), ALK (anaplastic lymphoma kinase), BRAF (v-Raf murine sarcoma viral oncogenic homolog B) [13, 14].

Looking for new and better treatment of patients with lung tumors, new compounds are constantly being tested as potential new drugs in vitro (Table 1).

Table 1. Active substances and antibodies for in vitro research of NSCLC

\begin{tabular}{|c|c|c|}
\hline $\begin{array}{l}\text { Natural } \\
\text { compounds }\end{array}$ & $\begin{array}{l}\text { Chemical } \\
\text { substances }\end{array}$ & $\begin{array}{l}\text { Immunology } \\
\text { Antibodies }\end{array}$ \\
\hline $\begin{array}{l}\text { Resveratrol [15] } \\
\text { Cordycepin [16] } \\
\text { Chelidonine [17] } \\
\text { Osthole [18] } \\
\text { Curcumin [19] } \\
\text { Cypripedin [20] }\end{array}$ & $\begin{array}{l}\text { Platinum-DNA } \\
\text { adducts [7] } \\
\text { Berberine- } \\
\text { hydrochloride [8] } \\
\text { Metformin [22] } \\
\text { Quinacrine [23] } \\
\text { Pimozide [24] } \\
\text { Nelfinavir [25] }\end{array}$ & $\begin{array}{l}\text { Imgatuzumab [25] } \\
\text { Cetuximab, } \\
\text { Necitumumab } \\
\text { [26], } \\
\text { Panitumumab, } \\
\text { Matuzumab, } \\
\text { Nimotuzumab }\end{array}$ \\
\hline
\end{tabular}

Berberine hydrochloride, platinum-DNA adducts, nitrogen heterocyclines are just some of the examples $[7,8,21]$. More and more scientific papers confirm that polychemio-therapy or their combinations in synergistic action of different compounds can be useful against cancer. Synergistic action enables the targeting of several targets of key signaling pathways that one drug alone fails. In cell line research, the synergy between the most commonly used TKIs was confirmed, as well as the combination of TKIs with other pharmacological substances [28, 29]. In addition to compounds that directly induce apoptosis, several chemicals have been described with the possibility to mediate and accelerate this process in combination with other compounds. Metformin and cypripedin as active chemicals, in combination with standard therapy (cisplatin), have higher activity and give better results in apoptosis induction [20, 22].

Compounds used in the treatment of various nonmalignant diseases could be potentially applied in NSCLC. They include quinacrine (anti-malarial drug), pimozide (anti-dyskinesia agent) and nelfinavir (an antiretroviral drug) [23, 24, 25].

\section{THE MOST COMMONLY USED METHODS FOR IN-VITRO TESTING OF NSCLC}

Some of the methods used in last period for in-vitro investigation of NSCLC include MTT assay, Flow cytometry, Western blot and CRISPR/cas9.

\subsection{MTT assay}

MTT

(3-(4,5-dimethylthiazol-2-yl)-2,5diphenyltetrazolium bromide) assay is the most used cell viability and proliferation assay since it was described in 1983 [30]. The essence of the reaction is that mitochondrial enzyme succinate-dehydrogenase reducts yellow tetrazolium salt in the blue colored formazan (Figure 2).

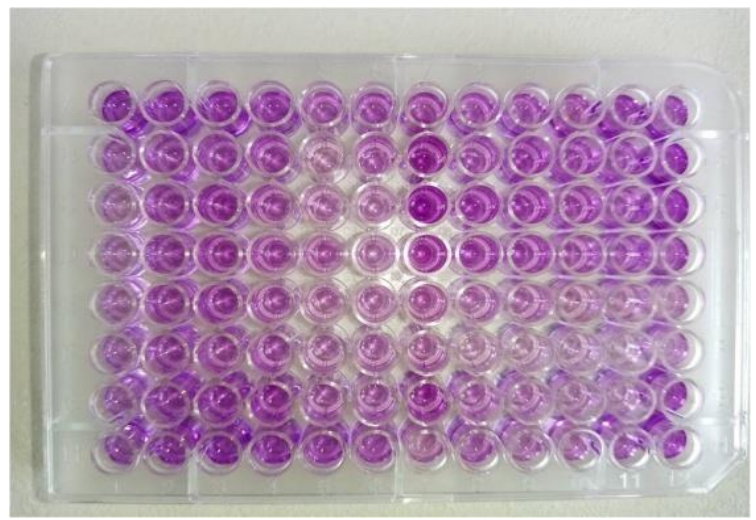

Figure 2. MTT test values; 96 microwell plates during the testing of the effects of chemical compounds

This test is an accurate indicator of cell viability because only enzymes from the active mitochondria of living cells lead to a reduction. The main disadvantage is that this conversion depends on metabolic rates and the number of mitochondria [31]. This method is suitable for high-throughput screening and miniaturization but requires numerous wash steps. The alternative to MTT assay might be the resazurin assay (RES), neutral red uptake (NRU), and sulforhodamine B (SRB) assays [32, 33]. Two more alternatives to the MTT test should be mentioned, and they are MTS (3- (4,5-dimethylthiazole-2-yl) $\quad 5^{-} \quad$ (3carboxymethoxyphenyl) -2- (4-sulfophenyl) $-2 \mathrm{H}-$ tetrazolium) and XTT (2,3-bis (2-methoxy-4-nitro-5sulfophenyl) $)-5-[($ phenylamino $)$ carbonyl $]-2 \mathrm{H}-$ tetrazolium hydroxide) assay [31, 19].

Using MTT assay, it is possible to investigate the effects of new synthesized chemicals or natural compounds with potential anti-proliferative effects on cancer cells as well as to assess the optimal concentration for application without toxicity [34]. Based on the $\mathrm{IC}_{50} \mathrm{O}$ value, it can be concluded which treatment and which concentration give the best results. Besides, the activity of the chemicals at different exposure times and whether the data have statistical significance are monitored. Anticancer activity in NSCLC cells has been confirmed using different natural origin compounds including Resveratrol, Cordycepin, Chelidonine $[15,16,17]$.

\subsection{Flow cytometry}

Flow cytometry is a modern multi-parameter technique for the biomedical study of cell characterization that generates information from the interaction of individual cells labeled with multicolor antibodies in cell suspension and a laser light reflection for cell detection [35]. Cell classification is performed based on size and granularity. Using these methods, individual cell receptors, cell antigens, degree of apoptosis, necrosis, and cell proliferation can be 
analyzed. Advances in technology have enabled the simultaneous measurement of as many as 40 markers on the cell surface [36]. Flow cytometry has advanced a lot in the last 30 years, mostly in the field of cell biology [35]. Until the discovery of monoclonal antibodies, flow cytometry was used only to measure the amount of DNA in cancer cells [37]

Flow cytometry is based on the estimation of marker expression on the cell membrane using Annexin V (Annexin A5) and Propidium iodide for assessing the percentage of apoptosis [38]. In addition to these two, the terminal deoxynucleotidyl transferase (TdT) and acridine orange (AO) are used, and the results show whether there are breaks in the DNA and the type of cell death. Surface marker testing and cell cycle phase testing are equally important. From such research, conclusions can be drawn as to which substances lead to programmed cell death, as well as at what stage of the cell cycle they are most sensitive [18]. New principles of immunotherapy based on genetically engineered newly synthesized antibodies directed against anti-epidermal growth factor receptor (EGFR) have shown the ability to induce antibody-dependent cellular cytotoxicity (ADCC) and inhibit EGFR signaling. They also confirmed first in vitro conditions and estimated degree of apoptosis [26].

Flow cytometry immune profiling, immune cellbased biomarker signatures and immunotherapy, cell cycle distribution and apoptosis are the main possibilities of the flow cytometry method in NSCLC studies $[9,37]$. This information is necessary to evaluate the effectiveness of therapy in the treatment of NSCLC. The introduction of specially designed antibodies confirms various signal pathways or parts of them. One example is the use of the anti-epidermal growth factor receptor - MB-encapsulated thiol-terminated silica nanoparticles (anti-EGFR/MB-SHSi) - for tumor detection [39]. That "Lab-on-a-chip platforms" are the future of molecular biology and medicine is also confirmed by new biotechnological discoveries by flow cytometry [40].

\subsection{Western blot}

In addition to the investigation of the genomic in NSCLC cell line, information about the protein state in the cells (proteomics) is very important. The most widely used technique over the last three decades to detect specific and the target protein has been a Western blot. Western blot is a method that examines the level of expression of a protein of interest and its phosphorylation status usually during the investigation of cell signaling.

This method consists of several steps, the first of which is the preparation of a cell lysate [41]. After appropriate homogenization or ultrasonic treatment of the cell lysate, denaturation of higher structures is necessary while preserving the negative charge. The negative charge is required for the proteins to separate in the process of electrophoresis, and then transferred to the membrane. Washing, blocking nonspecific antibody binding, and incubating the right antibody concentration are essential to minimize unbound antibodies in the background. We say that the Western blot method is semiquantitative because it does not show the absolute amount of protein of interest, but compares it with a predetermined control (Beta-actin) [38].
The main directions of research in NSCLS include an examination of changes in different cell markers and key signaling pathways during apoptosis (42, 43]. Advances in biotechnology are seen in the design of highly specific antibodies with high sensitivity. It is equally important that the test is cost-effective and that results in mutant EGFR are obtaining quickly. The Western blot method on the NSCLC model system is also used to investigate the effect of potential vaccines, substances of natural origin and drugs on the concentration and phosphorylation of EGFR protein $[19,42,43]$. Data about protein investigation indicate their regulatory role for EGFR signaling in NSCLC and give more information about several proteins like some of the fusion proteins that contribute to the oligomerization of the tyrosine kinase (EGFR) domain [44].

Western blotting has been used to investigate protein expression of circulating tumor cells (CTCs), cell migration, drug resistance as well as signaling pathways that are crucial for NSCLC cell survival and proliferation [45]. The results of protein testing help in the choice of therapy and also in understanding the benefits of vaccination in patients with NSCLC $[42,43,46]$. This method has advanced tremendously in the last decade and is becoming a more automated technique. The sensitivity and reliability of the method had been increased with the use of new automated western blotting machines, chemi-luminescent reagents, and imagers [47]. Changes in the material for separation, imaging and software data processing are responsible for this progress [48].

\subsection{CRISP/cas9}

Scientific research is not only based on availability and designed model systems. With the help of genetic engineering methods, they predict mutations of interest and direct the development of new model systems. CRISPR (clustered regularly interspaced palindromic repeats) technology allows us to examine in vitro how cell functions change with genome editing. An example is the insertion of 20 exons of the EGFR gene in NSCLC [49].

Results of the CRISP/cas9 study on NSCLC cell lines show great potential in the treatment of patients with this type of tumor. The application of the CRISP/cas9 method in gefitinib TKI-resistant H1975 cells has shown the possibility of editing mutations of interest [50]. Elimination of mutant EGFR alleles leading to drug resistance (L858R) occurs to cell death and tumor reduction after treatment. The unique CRISP/cas9 method in NSCLC cell line studies cannot be omitted. CRISPR technology allows us to examine in vitro how cell function changes with genome editing.

\section{NEW POSSIBILITIES AND PERSPECTIVES IN NSCLC RESEARCH AND TREATMENT}

In vitro research has great potential for discovering new target biomarkers and a better understanding of already discovered ones. For in vitro research to be valid, a reliable model must meet certain conditions. The cell line must maintain consistency and purity to be the right preclinical model. Infections (usually mycoplasma) and mixing of cell cultures are mentioned 
as the most common problems in the study of cell lines [3]. Cell line research has a wide range of studies.

In vitro studies are suitable for testing such models of therapy that cannot be immediately applied in humans, such as determining the dose and type of radiotherapy, where they were previously a good model of testing. Recently, there have been very intensive studies of the combination of radio and immunotherapy depending on the expression and/or mutation of EGFR [9]. Data have shown that EGFR mutated cells are more sensitive to radiation and suffer cell death by apoptosis. It is an important guideline for further clinical trials.

One of the technology novelties in basic research with cell culture has given a new model of threedimensional cell culture (3D cell culture) [51]. The advantages of new $3 \mathrm{D}$ model systems and highthroughput screening (HTS) tests are much more significant than "ordinary" preclinical drug trials. Cytotoxicity information is only part of the results. With the help of new methods, it is possible to identify a key signal pathway and what the response to e. g. transcription level is. The main conclusion is that the new $3 \mathrm{D}$ models better simulate the conditions prevailing in-vivo systems, mostly under the influence of extracellular matrix proteins [52].

Research into NSCLC cell lines for testing cell death, signaling pathways and bioactive substances are only a part of the possibility. The mixed methods research that will connect the active substance, signaling pathway and apoptotic death of cancer cells is the most important. Bufalin and PI3K/Akt Pathway, or Sesamin and Akt / p53 pathway in the induction of apoptosis are examples of multi-method works that give the complete picture of the subject of research [53, 54].

Resistance to TKI occurs in a large number of patients with NSCLC. The mechanisms of resistance in genes, such as HER2 and BRAF, have been insufficiently investigated, and resistant mutations in EGFR, c-MET, and ALK genes are best explained using classical methods based on Polymerase chain reaction (PCR) tests. [14]. Although the key genes involved in the development of resistance are known, patients still die from NSCLC.

This means that new target biomarkers must be set, and in this way targeted therapy should be improved. The first step is research involves in vitro studies on cell lines.

\section{CONCLUSION}

Mutation status, cell proliferation, expression and phosphorylation of proteins and cell cycle distribution provide complete information about cancer physiology and cancer growth. Literature data suggest that multi-method research and mixed investigation are important in the future for a better understanding of this complex process.

Besides, several techniques such as qPCR-HRM, MTT assay, Western blot and Flow cytometry need to be simultaneously applied [21, 42, 55].

Continuous investigation effects of a new potential drug are very important in oncology with aims to achieve better benefits to patients. Basic research is the one that provides guidelines for clinical research. It is equally important to examine whether the test compounds have toxic effects on healthy cells and whether their application would do more harm than good.

Future research should provide conclusions and guidelines on new therapeutic strategies in the treatment of NSCLC, as the emergence of drug resistance in patients is a major problem.

Cell lines are a good model on which the synergy of biotechnology and medicine can identify the key causes of tumor formation, angiogenesis, and metastasis. Advances in technology in the field of $3 \mathrm{D}$ cultures, organoids and knockout cell lines, make it possible to better understand the property of tumor heterogeneity in vitro.

Acknowledgements: This work was financially supported by the Ministry of Education, Science and Technological Development, Republic of Serbia, 175056 .

\section{REFERENCES}

1. F. Bray et al., "Global cancer statistics 2018: GLOBOCAN estimates of incidence and mortality worldwide for 36 cancers in 185 countries," CA Cancer J. Clin., vol. 68, no. 6, pp. $394-424$, Nov. 2018

DOI: $10.3322 /$ caac. 21492

PMid: 30207593

2. J. R. Molina, P. Yang, S. D. Cassivi, S. E. Schild, A. A. Adjei, "Non-small cell lung cancer: epidemiology, risk factors, treatment, and survivorship," Mayo Clin. Proc., vol. 83, no. 5, pp. $584-594$, May 2008.

DOI: $10.4065 / 83 \cdot 5 \cdot 584$

PMid: 18452692

PMCid: PMC2718421

3. J. L. Mulshine et al., "From clinical specimens to human cancer preclinical models-a journey the NCI-cell line database-25 years later," J. Cell. Biochem., vol. 121, no. 8 - 9, pp. 3986 - 3999, Dec. 2019.

DOI: $10.1002 /$ jcb.29564

PMid: 31803961 PMCid: PMC7496084

4. R. Zdanowski, M. Krzyżowska, D. Ujazdowska, A. Lewicka, S. Lewicki, "Role of a7 nicotinic receptor in the immune system and intracellular signaling pathways," Cent. Eur.J. Immunol., vol. 40, no. 3, pp. 373 - 379, 2015 DOI: $10.5114 /$ ceji.2015.54602

PMid: 26648784

PMCid: PMC4655390

5. N. Somensi et al., "Extracellular HSP7O Activates ERK1/2, NF-kB and Pro-Inflammatory Gene Transcription Through Binding with RAGE in A549 Human Lung Cancer Cells," Cell. Physiol. Biochem., vol. 42, no. 6, pp. 2507 - 2522, 2017.

DOI: $10.1159 / 000480213$

PMid: 28848092

6. E. Fokkema et al., "The role of apoptosis-related genes in non-small-cell lung cancer," Clin. Lung Cancer, vol. 4 no. 3, pp. $174-182$, Nov. 2002.

DOI: 10.3816/CLC.2002.n.025

PMid: 14706167

7. S. Cuello-Nuñez et al., "A species-specific double isotope dilution strategy for the accurate quantification of platinum-GG adducts in lung cells exposed to carboplatin," J. Anal. At. Spectrom., vol. 32, no. 7, pp. 1320 - 1330, Jun. 2017. DOI: $10.1039 / \mathrm{C} 7 \mathrm{JAO0078B}$

8. J. $\mathrm{Li}$ et al., "Berberine hydrochloride inhibits cell proliferation and promotes apoptosis of non-small cell lung cancer via the suppression of the MMP2 and Bcl-2/Bax signaling pathways," Oncol. Lett., vol. 15, no. 5 , pp. 7409 - 7414, May 2018.

DOI: $10.3892 /$ ol.2018.8249

PMid: 29725453 
PMCid: PMC5920480

9. B. Xie et al., "Epidermal growth factor receptor gene mutations in non-small-cell lung cancer cells are associated with increased radiosensitivity in vitro," Cancer Manag. Res., vol. 10, pp. 3551 - 3560, Sep. 2018. DOI: 10.2147/CMAR.S165831

PMid: 30271203 PMCid: PMC6145635

10. J. Obradović et al., "Frequencies of EGFR single nucleotide polymorphisms in non-small cell lung cancer patients and healthy individuals in the Republic of Serbia: a preliminary study," Tumor Biology, vol. 37, no. 8, pp. $10479-10486$, Aug. 2016.

DOI: $10.1007 / \mathrm{s} 13277-016-4930-4$

PMid: 26846215

11. V. Jurišić, J. Obradović, S. Pavlović, N. Djordjević, "Epidermal Growth Factor Receptor Gene in Non-SmallCell Lung Cancer: The Importance of Promoter Polymorphism Investigation," Anal. Cell. Pathol. (Amst). vol. 2018, article no. 6192187, Oct. 2018

DOI: $10.1155 / 2018 / 6192187$

PMid: 30406002

PMCid: PMC6204164

12. V. Jurišić et al., "EGFR Polymorphism and Survival of NSCLC Patients Treated with TKIs: A Systematic Review and Meta-Analysis," J. Oncol., vol. 2020, spec. issue, article no. 1973241, Mar. 2020

DOI: $10.1155 / 2020 / 1973241$

PMid: 32256580

PMCid: PMC7104312

13. I. Chaib et al., "Co-activation of STAT3 and YESAssociated Protein 1 (YAP1) Pathway in EGFR-Mutan NSCLC," J. Natl. Cancer Inst., vol. 109, no. 9, Sep. 2017. DOI: $10.1093 /$ jnci/djxo14

PMid: 28376152

PMCid: PMC5409000

14. Z. Schrank et al., "Current Molecular-Targeted Therapies in NSCLC and Their Mechanism of Resistance," Cancers, vol. 10, no. 7, article no. 224, Jul. 2018.

DOI: $10.3390 /$ cancers10070224

PMid: 29973561

PMCid: PMC6071023

15. M. Yousef, I. A. Vlachogiannis, E. Tsiani, "Effects of Resveratrol against Lung Cancer: In Vitro and In Vivo Studies," Nutrients, vol. 9, no. 11, article no. 1231, Nov. 2017.

DOI: $10.3390 /$ nu9111231

PMid: 29125563

PMCid: PMC5707703

16. Z. Wang et al., "Cordycepin Induces Apoptosis and Inhibits Proliferation of Human Lung Cancer Cell Line H1975 via Inhibiting the Phosphorylation of EGFR," Molecules, vol. 21, no. 10, article no. 1267, Sep. 2016.

DOI: 10.3390/molecules21101267

PMid: 27689974

PMCid: PMC6274019

17. Y.J. Xie et al., "Chelidonine selectively inhibits the growth of gefitinib-resistant non-small cell lung cancer cells through the EGFR-AMPK pathway," Pharmacol. Res., vol. 159, article no. 104934, Sep. 2020.

DOI: 10.1016/j.phrs.2020.104934

PMid: 32464330

18. X. Xu, Y. Zhang, D. Qu, T. Jiang, S. Li, "Osthole induces $\mathrm{G} 2 / \mathrm{M}$ arrest and apoptosis in lung cancer A549 cells by modulating PI3K/Akt pathway," J. Exp. Clin. Cancer Res., vol. 30, no. 1, article no. 33, Mar. 2011.

DOI: $10.1186 / 1756-9966-30-33$

PMid: 21447176

PMCid: PMC3073874

19. L. Zhang et al., "Curcumin inhibits cell proliferation and migration in NSCLC through a synergistic effect on the TLR4/MyD88 and EGFR pathways," Oncol. Rep., vol. 42, no. 5, pp. $1843-1855$, Nov. 2019.

DOI: $10.3892 /$ or.2019.7278

PMid: 31432177

PMCid: PMC677580o
20. O. Wattanathamsan, S. Treesuwan, B. Sritularak, V. Pongrakhananon, "Cypripedin, a phenanthrenequinone from Dendrobium densiflorum, sensitizes non-small cell lung cancer $\mathrm{H} 46 \mathrm{O}$ cells to cisplatin-mediated apoptosis," J. Nat. Med., vol. 72, no. 2, pp. 503 - 513, Mar. 2018.

DOI: $10.1007 / \mathrm{s} 11418-018-1176-\mathrm{Z}$

PMid: 29426985

21. L. Liu et al., "PTEN inhibits non-small cell lung cancer cell growth by promoting $\mathrm{G}_{\mathrm{o}} / \mathrm{G}_{1}$ arrest and cell apoptosis," Oncol. Lett., vol. 17, no. 1, pp. 1333 - 1340, Jan. 2019.

DOI: $10.3892 / 01.2018 .9719$

PMid: 30655903

PMCid: PMC6313010

22. M. Moro et al., "Metformin Enhances Cisplatin-Induced Apoptosis and Prevents Resistance to Cisplatin in Co-mutated KRAS/LKB1 NSCLC," J. Thorac. Oncol., vol. 13, no. 11, pp. $1692-1704$, Nov. 2018.

DOI: $10.1016 /$ j.jtho.2018.07.102

PMid: 30149143

23. M. Kumar et al., "Quinacrine inhibits GSTA1 activity and induces apoptosis through $\mathrm{G}_{1} / \mathrm{S}$ arrest and generation of ROS in human non-small cell lung cancer cell lines," Oncotarget, vol. 11, no. 18, pp. 1603 - 1617, May 2020.

DOI: $10.18632 /$ oncotarget.27558

PMid: 32405336 PMCid: PMC7210017

24. B. Li et al., "A novel drug repurposing approach for nonsmall cell lung cancer using deep learning," PLoS One, vol. 15, no. 6, article no. eo233112, Jun. 2020.

DOI: 10.1371/journal.pone.0233112

PMid: 32525938

PMCid: PMC7289363

25. V. Parvathaneni, M. Goyal, N. S. Kulkarni, S. K. Shukla, V. Gupta, "Nanotechnology Based Repositioning of an Anti-Viral Drug for Non-Small Cell Lung Cancer (NSCLC)," Pharm. Res., vol. 37, no. 7, article no. 123, Jun. 2020.

DOI: $10.1007 / \mathrm{s} 11095-020-02848-2$

PMid: 32514688

26. A. Kol et al., "ADCC responses and blocking of EGFRmediated signaling and cell growth by combining the antiEGFR antibodies imgatuzumab and cetuximab in NSCLC cells," Oncotarget, vol. 8, no. 28, pp. 45432 - 45446 , Jul. 2017.

DOI: 10.18632/oncotarget.17139

PMid: 28467975

PMCid: PMC5542198

27. F. Agustoni, et al., "EGFR-directed monoclonal antibodies in combination with chemotherapy for treatment of non-small-cell lung cancer: an updated review of clinical trials and new perspectives in biomarkers analysis," Cancer Treat. Rev., vol. 72, pp. $15-27$, Jan. 2019.

DOI: $10.1016 /$ j.ctrv.2018.08.002 PMid: 30445271

28. Z. Yang, K. Y. Tam, "Anti-cancer synergy of dichloroacetate and EGFR tyrosine kinase inhibitors in NSCLC cell lines," Eur. J. Pharmacol., vol. 789, pp. $458-467$, Oct. 2016.

DOI: 10.1016/j.ejphar.2016.08.004 PMid: 27514773

29. J. Zhao, A. Guerrero, K. Kelnar, H. J. Peltier, A. G. Bader, "Synergy between next generation EGFR tyrosine kinase inhibitors and miR-34a in the inhibition of non-small cell lung cancer," Lung Cancer, vol. 108, pp. 96 - 102, Jun. 2017.

DOI: 10.1016/j.lungcan.2017.02.020

PMid: 28625657

30. T. Mosmann, "Rapid colorimetric assay for cellular growth and survival: application to proliferation and cytotoxicity assays," J. Immunol. Methods, vol. 65, no. $1-2$, pp. $55-63$, Dec. 1983.

DOI: 10.1016/0022-1759(83)90303-4 PMid: 6606682

31. A. van Tonder, A. M. Joubert, A. D. Cromarty, "Limitations of the 3-(4,5-dimethylthiazol-2-yl)-2,5diphenyl-2H-tetrazolium bromide (MTT) assay when 
compared to three commonly used cell enumeration assays," BMC Res. Notes, vol. 8, no. 1, article no. 47, Feb. 2015.

DOI: $10.1186 / \mathrm{s} 13104-015-1000-8$

PMid: 25884200

PMCid: PMC4349615

32. Y. L. Li et al., "Shikonin sensitizes wild-type EGFR NSCLC cells to erlotinib and gefitinib therapy," Mol. Med. Rep., vol. 18 , no. 4, pp. $3882-3890$, Oct. 2018.

DOI: $10.3892 / \mathrm{mmr} .2018 .9347$

PMid: 30106133

PMCid: PMC6131653

33. B. Toviwek, P. Suphakun, K. Choowongkomon, S. Hannongbua, M. P. Gleeson, "Synthesis and evaluation of the NSCLC anti-cancer activity and physical properties of 4-aryl-N-phenylpyrimidin-2-amines," Bioorganic Med. Chem. Lett., vol. 27, no. 20, pp. 4749 - 4754, Oct. 2017.

DOI: 10.1016/j.bmcl.2017.08.063

PMid: 28927795

34. R. Noro et al., "Gefitinib (IRESSA) sensitive lung cancer cell lines show phosphorylation of Akt without ligand stimulation," BMC Cancer, vol. 6, no. 1, article no. 277, Dec. 2006.

DOI: 10.1186/1471-2407-6-277

PMid: 17150102

PMCid: PMC1698934

35. K. M. McKinnon, "Flow Cytometry: An Overview," Curr. Protoc. Immunol., vol. 120, no. 1, pp. 5.1.1 - 5.1.11, Feb. 2018.

DOI: $10.1002 /$ cpim.40

PMid: 29512141

PMCid: PMC5939936

36. V. Pillai, D. M. Dorfman, "Flow Cytometry of Nonhematopoietic Neoplasms," Acta Cytol., vol. 60, no. 4, pp. $336-343,2016$.

DOI: $10.1159 / 000448371$

PMid: 27578265

37. M. Danova et al., "The role of automated cytometry in the new era of cancer immunotherapy," Mol. Clin. Oncol., vol. 9, no. 4, pp. $355-361$, Oct. 2018.

DOI: $10.3892 /$ mco.2018.1701

PMid: 30233791

PMCid: PMC6142305

38. V. Jurišić, T. Srdić-Rajić, G. Konjević, G. Bogdanović, M. Čolić, "TNF- $\alpha$ induced apoptosis is accompanied with rapid CD30 and slower CD45 shedding from K-562 cells," J. Membr. Biol., vol. 239, no. 3, pp. 115 - 122, Feb. 2011. DOI: $10.1007 /$ soo232-010-9309-7 PMid: 21221555

39. J. Wan, W. Wu, R. Zhang, S. Liu, Y. Huang, “Anti-EGFR antibody conjugated silica nanoparticles as probes for lung cancer detection," Exp. Ther. Med., vol. 14, no. 4, pp. $3407-3412$, Oct. 2017.

DOI: $10.3892 /$ etm.2017.4988

PMid: 29042926

PMCid: PMC5639344

40. A. Vembadi, A. Menachery, M. A. Qasaimeh, "Cell Cytometry: Review and Perspective on Biotechnological Advances," Front. Bioeng. Biotechnol., vol. 7, article no. 147, Jun. 2019.

DOI: $10.3389 /$ fbioe.2019.00147

PMid: 31275933

PMCid: PMC6591278

41. T. Mahmood, P. C. Yang, "Western blot: technique, theory, and trouble shooting," N. Am. J. Med. Sci., vol. 4, no. 9 , pp. $429-434$, Sep. 2012.

DOI: $10.4103 / 1947-2714.100998$

PMid: 23050259

PMCid: PMC 3456489

42. M. Forcella et al., "Non-small cell lung cancer (NSCLC), EGFR downstream pathway activation and TKI targeted therapies sensitivity: Effect of the plasma membraneassociated NEU3," PLoS One, vol. 12, no. 10, article no. e0187289, Oct. 2017.

DOI: 10.1371/journal.pone.0187289

PMid: 29088281
PMCid: PMC5663482

43. J. Codony-Servat et al., "Cancer Stem Cell Biomarkers in EGFR-Mutation-Positive Non-Small-Cell Lung Cancer," Clin. Lung Cancer, vol. 20, no. 3, pp. 167 - 177, May 2019. DOI: 10.1016/j.cllc.2019.02.005 PMid: 30885551

44. K. Konduri et al., "EGFR Fusions as Novel Therapeutic Targets in Lung Cancer," Cancer Discov., vol. 6, no. 6, pp. $601-611$, Jun. 2016.

DOI: $10.1158 / 2159-8290 . C D-16-0075$

PMid: 27102076

PMCid: PMC4893907

45. E. Sinkala et al., "Profiling protein expression in circulating tumour cells using microfluidic western blotting," Nat. Commun., vol. 8, article no. 14622, Mar. 2017.

DOI: $10.1038 /$ ncomms 14622

PMid: 28332571

PMCid: PMC5376644

46. E. Banno et al., "Afatinib is especially effective against non-small cell lung cancer carrying an EGFR exon 19 deletion," Anticancer Res., vol. 35, no. 4, pp. 2005 - 2008, Apr. 2015. PMid: 25862853

47. R. Ghosh, J. E. Gilda, A. V. Gomes, "The necessity of and strategies for improving confidence in the accuracy of western blots," Expert Rev. Proteomics, vol. 11, no. 5, pp. $549-560$, Oct. 2014.

DOI: $10.1586 / 14789450.2014 .939635$

PMid: 25059473

PMCid: PMC4791038

48. M. Mishra, S. Tiwari, A. V. Gomes, "Protein purification and analysis: next generation Western blotting techniques," Expert Rev. Proteomics, vol. 14, no. 11, pp. 1037 - 1053, Nov. 2017.

DOI: $10.1080 / 14789450.2017 .1388167$

PMid: 28974114

PMCid: PMC6810642

49. A. Leonetti et al., "Resistance mechanisms to osimertinib in EGFR-mutated non-small cell lung cancer," $\mathrm{Br}$. $J$. Cancer, vol. 121, no. 9, pp. 725 - 737, Oct. 2019.

DOI: $10.1038 / \mathrm{s} 41416-019-0573-8$

PMid: 31564718

PMCid: PMC6889286

50. T. Koo et al., "Selective disruption of an oncogenic mutant allele by CRISPR/Cas9 induces efficient tumor regression," Nucleic Acids Res., vol. 45, no. 13, pp. $7897-7908$, Jul. 2017.

DOI: $10.1093 /$ nar/gkx490

PMid: 28575452

PMCid: PMC5570104

51. R. Alföldi et al., "Single Cell Mass Cytometry of Non-Small Cell Lung Cancer Cells Reveals Complexity of In vivo And Three-Dimensional Models over the Petri-dish," Cells, vol. 8, no. 9, article no. 1093, Sep. 2019.

DOI: $10.3390 /$ cells8091093

PMid: 31527554

PMCid: PMC6770097

52. W. Jia et al., "Effects of three-dimensional collagen scaffolds on the expression profiles and biological functions of glioma cells," Int. J. Oncol., vol. 52, no. 6, pp. $1787-1800$, Jun. 2018.

DOI: 10.3892/ijo.2018.4330

PMid: 29568859 PMCid: PMC5919708

53. Z. Zhu et al., "Bufalin induces lung cancer cell apoptosis via the inhibition of $\mathrm{PI}_{3} \mathrm{~K} /$ Akt pathway," Int. J. Mol. Sci., vol. 13, no. 2, pp. 2025-2035, 2012.

DOI: $10.3390 / \mathrm{ijms} 13022025$

PMid: 22408435

PMCid: PMC 3292004

54. Y. Chen et al., "Sesamin suppresses NSCLC cell proliferation and induces apoptosis via Akt/p53 pathway," Toxicol. Appl. Pharmacol., vol. 387, article no. 114848, Jan. 2020. DOI: $10.1016 / j$.taap.2019.114848 PMid: 31809756 
55. D. Wang, B. Bao, "Gallic Acid Impedes Non-Small Cell Lung Cancer Progression via Suppression of EGFRDependent CARM1-PELP1 Complex," Drug Des. Dev. Ther., vol. 14, pp. 1583 - 1592, Apr. 2020.
DOI: 10.2147/DDDT.S228123

PMid: 32425504

PMCid: PMC7186892 